\title{
Bibliography
}

\author{
Archives
}

British Library

Imperial War Museum

Museum of Military Medicine (formerly Army Medical Museum)

The National Archives, Kew

Princess Mary's Royal Air Force Nursing Service Archive

Royal College of Nursing Archive, Edinburgh

Wellcome Library, London

\section{Oral histories}

(Unless otherwise stated all oral histories are held at the UK Centre for the History of Nursing, at the University of Manchester)

Bowring, Elizabeth, oral history interview via telephone by Jane Brooks, 31 July 2012

Carr, Joan, oral history interview by Jane Brooks, at her home in the north-west of England, 22 November 2013.

Cash, Marion, oral history interview via telephone by Jane Brooks, 23 October 2013.

Cheetham, John, oral history interview by Jane Brooks, at his home in the northwest of England, 8 September 2012.

Christie, Cecelia Helen Burnette, oral history interview by Conrad Wood, 25 March 1993, IWM Sound Archive, 13121

Clarke, Jean, oral history interview via telephone by Jane Brooks, 20 November 2013.

Cooper, Gertrude Annie, oral history interview by Margaret Skellern, 10 May 1994. Royal College of Nursing Oral History Archive, Edinburgh.

Cottrell, Evelyn Alma, Spears Unit, oral history interview by Lyn E. Smith, 9 July 1990, IWM Oral History Collection, Interview 12180. 
Crisp, Betty, oral history interview via telephone by Jane Brooks, 13 January 2014.

Davies, Elsie, oral history interview by Jane Brooks at her home in Manchester, 18 December 2012.

Dowling, Ursula, oral history interview by Rosemary Hart on behalf of the BBC, 1986, IWM Oral History Collection, Interview 9910.

Dunnett, Amy Selina (Pam), oral history interview by Lyn E. Smith, 25 March 1999, IWM Sound Archive, 18784.

Edwards, Jean, oral history interview via telephone by Jane Brooks, 6 November 2013.

Evans, Betty, oral history interview via telephone by Jane Brooks, 10 January 2014.

'Frontline Females', BBC Radio 4, 11 April 1998 and 18 April 1998: British Library Sound Archive H9872/2 and H9890/2. In this programme Claire Rayner discussed their wartime nursing experiences with Monica Baly, Mary Bates, Glenys Branson, Constance Collingwood, Gertrude Cooper, Ursula Dowling, Brenda Fuller, Anne Gallimore, Monica Goulding, Daphne Ingram, Anita Kelly, Margaret Kneebone, Sylvia Mayo, Kay McCormack, Anne Moat, Phyllis Thoms and Margot Turner.

Haddie Swan, Mary, oral history interview by Lyn E. Smith, 26 October 1998, IWM Sound Archive, 18571.

Hamilton, June (pseudonym) oral history interview by Jane Brooks at her home in the south of England, 19 October 2011.

Hardy, Florence, born in 1916 and trained in London. Given Mrs Hardy's age it was not possible to interview her in person, but I liaised with her via her great friend Mr Cyril Fish via telephone, 5 December 2013.

Morris, Elizabeth, oral history interview via telephone by Jane Brooks, 8 October 2013.

Newton, Bessie, oral history interview by Jane Brooks, at her home in Yorkshire, 21 April 2012.

Nicolson, Joan Eileen, oral history by Conrad Wood, 8 June 1991, IWM Sound Archive 12075.

Parkes, Margaret, oral history interview by Jane Brooks at her home in the northwest of England, 12 December 2012.

Peake, Joan (nee Botting), oral history by her son, Andrew Peake, 17 March 1993, Royal College of Nursing Oral History Archive, Edinburgh.

Potter, Evelyn (pseudonym), oral history interview via telephone by Jane Brooks, 16 September 2013.

Slater, Rachel (pseudonym), oral history interview by Jane Brooks in the south of England, 20 October 2011.

Soper, Emily, oral history interview via the telephone by Jane Brooks, 6 September 2013. 


\section{Personal testimonies}

(Unless otherwise stated all personal testimonies are held at the UK Centre for the History of Nursing, at the University of Manchester)

Baker, C.M.S., 'Aftermath of war, September 1945' and 'A view of war by an officer of the QAIMNS, October 1943 to May 1945', Imperial War Museum Private Papers (hereafter IWM) Documents 6341.

Bower, Iris, OBE, ARRC, 'From Normandy to the Baltic' (October 1985).

Briggs, Phyllis Mary, 'Alor Star', IWM Documents 4419.

Brown, Francie E., letters to Mrs W.R. Trotman (10 September 1942-4 August 1944), IWM Documents 12472.

Butland, Catherine M., 'Army sisters in battledress or the chosen few or follow fate', MMM, QARANC/PE/1/74/BUTL Box 8.

Collins, Barbara, 'Letters home from Sierra Leone', 1940-1941.

Dyer, P.M., 'When life was grey and scarlet: A recollection of life as an Army Nursing Sister', MMM, QARANC/PE/1/151/DYER Box 8.

Elvidge, Kathleen J., 'Letter to "My Darling”' (26 May 1945), IWM Documents 1029.

Feggetter, George, 'Diary of an R.A.M.C. surgeon at war, 1942-1946', Wellcome Library, London, RAMC 1776.

Hutchinson, Catherine Arnold, 'My war and welcome to it' (2001), IWM Documents 11950.

Ingram, Daphne (nee de Wart), 'Experiences of an army nurse: POW with Japanese', IWM Documents 2319.

Jarrett, Nell, 'Diary of her desert experiences' (21 June 1942-13 January 1943).

Leeming, E.M., 'My war years, 1939-1945', Wellcome Library, London, PP/LEE.

Luker, Esther Helen Audrey, ARRC, 'Diaries from 1940-45', IWM Documents 1274.

McDonald, J.R., 'A doctor goes to war', Wellcome Library London, RAMC 944.

Morgan, Agnes Kathleen Dunbar, 'Still with the lamp: Letters to my mother by an army nursing sister. Egypt - North Africa - Sicily - Italy, 1941-1944', IWM Documents 16686.

Morris, Mary, 'The diary of a wartime nurse', IWM Documents 4850.

Mountford, Winifred Margaret (later Winstanley), 'Monty', unpublished memoir of her wartime experiences as a QAIMNS Sister in the Second World War.

Radloff, Ann, 'Going to Gooseberry Beach: Travels and adventures of a nursing sister', IWM Documents.147.

Salter, Muriel Kathleen (Penny), 'Long ago and far away: A distant memory': A diary, c. 1938-1970. There is also a copy of this diary in the IWM, Documents 17649.

Silva Jones, Molly, 'From a diary written in Belsen', IWM Documents 9550. 
Stevenson, Edith, 'The last lap: Autobiography 1912-1986', 3. IWM LBY 94 / 1636.

Wilson, Sister Jessie Sarah Catherine, 'We also served, 1940 ...'.

\section{Government and professional reports}

The Advisory Service of the Royal College of Nursing, 'The re-settlement of nurses: Back to civilian life' (London: H. and Co., December 1945).

The Lancet Commission on Nursing, Final Report (London: The Lancet, 1932).

Ministry of Health, Board of Education and Department of Health for Scotland

(Chairman, Earl of Athlone), Interim Report of the Inter-Departmental Committee on Nursing Services (London: HMSO, 1939).

Ministry of Health, First Report of Nurses' Salaries Committee (London: HMSO, 1943).

\section{Published primary sources}

Anonymous, 'The technique of blood transfusion', Nursing Mirror (2 September 1939): 764.

Anonymous, 'War - what it means to the nurse', Nursing Mirror and Midwives' Journal (2 September 1939): 755.

Anonymous, 'Editorial: Tannic acid "is out"', Nursing Mirror and Midwives' Journal (23 November 1940): 171.

Anonymous, 'Editorial: War-time advances and antiseptics', Nursing Times (11 April 1942): 237.

Anonymous, 'Nursing adventure: The story of two nursing sisters returning on the torpedoed "Rangitane", Nursing Times (25 October 1942): 672.

Anonymous, 'Penicillin saves wounded soldiers', The British Journal of Nursing (September 1943):104.

Anonymous, 'The nurse in charge', The Lancet (4 December 1943): 705.

Anonymous, 'Penicillin in the field', The Lancet (11 December 1943): 737.

Anonymous, 'News from the nursing world: Professor Florey on penicillin', Nursing Mirror and Midwives' Journal (18 December 1943): 161.

Anonymous, 'Penicillin in the treatment of war wounds', Nursing Times (8 January 1944): 19.

Anonymous, 'Editorial: Penicillin treatment reviewed', Nursing Times (22 April 1944): 275.

Anonymous, 'Topical notes - Normandy broadcast', Nursing Times (1 July 1944): 430.

Anonymous, 'In Step with the QAs 1. - An officer writes to his wife from the Anzio beachhead', Nursing Times (5 August 1944): 538.

Anonymous, 'In step with the QAs 8. - Hospital ship (Part I)', Nursing Times (30 September 1944): 678. 
Anonymous, 'In step with the QAs 9. - Hospital ship (part II)', Nursing Times (7 October 1944): 698.

Anonymous, 'Penicillin for P.O.W.', British Medical Journal (7 October 1944): 484.

Anonymous, 'Penicillin: Indications for its use and methods of administration', Nursing Mirror (14 April 1945): 16.

Anonymous, 'Penicillin: Indications for its use and methods of administration', The British Journal of Nursing (April 1945): 39.

Anonymous, 'Correspondence', The British Journal of Nursing (May 1945): $54-55$.

Anonymous, 'Editorial: The ward sister and professional organization', Nursing Times (11 August 1945): 513.

Anonymous, 'Editorial: Nursing goes forward', Nursing Times (17 November 1945): 751.

Anonymous, 'Higher pay for nurses', The Lancet (29 December 1945): 859.

Anonymous, 'Editorial: For the good of all', Nursing Times (19 January 1946): $41-42$.

Anonymous, 'Coming home - Army nurses think of demobilisation', Nursing Times (16 February 1946): 127.

Anonymous, 'Living out and living in', Nursing Mirror (2 March 1946): 361-2.

Anonymous, 'New Rushcliffe Committee scales for many nursing posts', The British Journal of Nursing (August 1946): 90.

Anonymous, 'Central Midwives Board. The pupil's case book', The Midwife: The British Journal of Nursing (February 1948): 24.

Anonymous, 'The grave shortage of nurses', The British Journal of Nursing (December 1948): 144.

B.B., Sister, 'Nursing in Belsen Camp', Nursing Times (14 July 1945): 204.

Barford, A.M., 'Nurse anaesthetics', British Medical Journal (5 October 1940): 474.

Bartlett, Dorothy A., Nurse in War (London: P.R. Macmillan, 1961).

Beardwell, Myrtle, Aftermath (Ilfracombe: Arthur Stockwell, c. 1953).

Bevington, Sheila M., Nursing Life and Discipline: A Study Based on Over Five Hundred Interviews (London: H.K. Lewis, 1943).

Bolton, Angela, The Maturing Sun: An Army Nurse in India 1942-45 (London: Headline, 1986).

Bond, Mary, Wartime Experiences from the Midnight Sun to Belsen (Cardigan: E.L. Jones and Son, 1994).

Bowden, Jean, Grey Touched with Scarlet: The War Experiences of Army Nursing Sisters (London: Robert Hale, 1959).

Bright, Pamela, Life in our Hands: Nursing Sister's War Experiences (London: Pan Books, 1955).

Bunyan, John, 'Treatment of wounds and burns by the envelope method', Nursing Times 72 (22 February 1941): supplement, ii-iii. 
Carter, Gladys B., 'Reconsideration of nursing: Its fundamentals, purposes and place in the community. 3. Recruitment and training of nurses', Nursing Mirror (1946): 316-18.

Dale, H.E., 'Modern drugs: 3 - Penicillin', Nursing Times (27 November 1943): 883.

Darley, V.E., 'Living out is not such an advantage', Nursing Mirror (23 March 1946): 424.

David, Lily Mary, 'The economic status of the nursing profession: A preliminary report of the socio-economic study, undertaken to reveal how nurses compare in their working and living conditions of women in other professions', The American Journal of Nursing 47, 7 (1947): 456-62.

de Pinto, J., 'A new plan for hospital staffs', Nursing Times (1 December 1945): 801.

Dick, Bruce M., 'Injuries and wounds of the chest', in J.M. Mackintosh, Wartime Nurse: An Anthology of Ideas about the Care and Nursing of War Casualties (Edinburgh: Oliver and Boyd, 1940).

Dickens, Monica, Chronicle of a Working Life: One Pair of Feet (Stroud: Sutton Publishing, 2004).

Edge, Geraldine, and Johnston, Mary E., Ships of Youth: The Experiences of Two Army Nursing Sisters on Board the Hospital Carrier Leinster (London: Hodder and Stoughton, 1945).

Elam, John, 'Anaesthesia in war-time', The Lancet (15 April 1939): 906.

Elam, John, 'Nurse anaesthetists', The British Medical Journal (14 September 1940): 368.

Emergency Medical Services, Ministry of Health, 'Memorandum: The treatment of burns', Nursing Times (5 April 1941): 242.

Fletcher, C.M., 'Penicillin: A recent advance in chemotherapy', Nursing Times (4 October 1941): 798-800.

Goode, Alan F., 'Correspondence', British Medical Journal (28 September 1940): 430.

Gordon, J. Elsie, 'With the BAFO and BAOR - 4: In the depressing city of Berlin', Nursing Times (8 December 1945): 157-8.

Gregg, Alan, 'Adaptation of survival: Reflections on our postwar problems', American Journal of Nursing 44, 10 (1944): 923.

Harries, E.H.R, Swyer, Robert, and Thompson, Noel, 'Sulphanilamide in typhoid fever', The Lancet (10 June 1939): 1321-4.

Harrison, Ada (ed.), Grey and Scarlet: Letters from the War Areas by Army Sisters on Active Service (London: Hodder and Stoughton, 1944).

Henderson, R.G., 'Treatment of incendiary bomb burns', Nursing Mirror (6 July 1940): 325-6.

Hilder, Joyce C., 'All in the day's work IV.- Darkest Africa!', Nursing Times 38, 1919 (7 February 1942): 93.

I.B.H., 'In step with the QAs 2. - Nursing in a psychiatric hospital for officers', Nursing Times (12 August 1944): 557. 
Jones, Dame Katharine, 'On active service with the Army', Nursing Times (25 September 1943): 719-20.

Jones, Dame Katharine, 'Broadcast talk to North America', The British Journal of Nursing (November 1943): 124-5.

Jones, Dame Katharine, 'QAIMNS professional and military status', Nursing Times (27 January 1945): 60-1, 67.

Jones, Katharine H., 'Introduction', in Ada Harrison (ed.), Grey and Scarlet: Letters from the War Areas by Army Sisters on Active Service (London: Hodder and Stoughton, 1944).

Jones, Katharine H., 'Miss Jane Amelia Patterson, CBE, RRC (late Chief Principal Matron, India, QAIMNS, 1922-1947)', in Queen Alexandra's Royal Army Nursing Corps Association, The Gazette 3, 6 (1958): 11.

Jones, Vera, A Time To Remember: A Record of Nursing Experiences, Impressions and Travels during World War II Contained in Letters Sent Home from the East (London: Athena Press, 2005).

K.M.C., 'In step with the QAs 6'. - Blitz on George Cross Island', Nursing Times (16 September 1944): 643-4.

La Motte, Ellen Newbold, The Backwash of War: The Human Wreckage of the Battlefield as Witnessed by an American Hospital Nurse (New York: G.P. Putnam's Sons, 2016).

Layton, T.B., 'Transport of wounded: Surgical aspects', The Lancet (23 March 1940): 537-40.

Learmonth, J.R., 'The surgical nurse', in J.M. Mackintosh, Wartime Nurse: An Anthology of Ideas about the Care and Nursing of War Casualties (Edinburgh: Oliver and Boyd, 1940).

Lipscombe, F.M., 'Medical aspects of Belsen concentration camp', The Lancet (8 September 1945): 313-15.

Logie, N.J., 'Treatment of burns in Tobruk', Nursing Mirror (10 July 1943): 230.

Love Tayloe, Roberta, Combat Nurse: A Journal of World War II (Santa Barbara, CA: Fithian Press, 1988).

McAdam, I.W.J., Duguid, J.P., and Challinor, S.W., 'Systemic administration of penicillin', The Lancet (9 September 1944): 336.

McBryde, Brenda, A Nurse's War (Saffron Walden: Cakebread Publications, 1993).

MacCormick, Iain, The Feminine Touch. Director, Pat Jackson (27 March 1956), Ealing Studios, www.imdb.com/title/tt0050428/ [accessed 28 September 2016].

McIndoe, Archibald H., 'Saline baths treatment for burns', Nursing Mirror (18 July 1942): i-ii.

Mackintosh, J.M., Wartime Nurse: An Anthology of Ideas about the Care and Nursing of War Casualties (Edinburgh: Oliver and Boyd, 1940).

MacNalty, Arthur Salusbury, 'Influence of war on family life', in Sir James Marchant (ed.), Rebuilding Family Life in the Post-War World: An Enquiry with Recommendations (London: Odhams Press, 1945). 
Mitchiner, Philip, 'Modern methods of treating war burns', Nursing Mirror (10 May 1943): 23-4.

Moody, Patricia, 'With pen and brush - a QA reports. 3. - When a ward is a tent', Nursing Times (25 November 1944): 810.

Moody, Patricia, 'With pen and brush - a QA reports. 4. - Night duty - with a difference', Nursing Times 40 (2 December 1944): 829.

Morris, Mary, A Very Private Diary: A Nurse in Wartime, ed. Carol Acton (London: Weidenfeld and Nicolson, 2014).

Murphy, J.D.F., 'The insulin coma unit in a military psychiatric division', Journal of the Royal Army Medical Corps 99 (1953): 232-43.

Nicol, A.A., My Moving Tent: Diary of a Desert Rat (Edinburgh: Pentland Press, 1994).

Nightingale, Florence, 'Subsidiary note as to the introduction of female nursing into military hospitals in peace and in war' (Thoughts submitted as to an eventual Nurses' Provident Fund), Presented to the Secretary of State for War (London: Harrison and Son, 1858).

Nightingale, Florence, Notes on Nursing: What It Is and What It Is Not (New York: Dover Publications, 1969).

Park, R.G., 'Cutaneous hypersensitivity to sulphonamides: A report of 12 cases', The British Medical Journal 2, 4306 (17 July 1943): 69-72.

Parkin, Betty C., Desert Nurse: A World War II Memoir (London: Robert Hale, 1990).

Parsons, F.B., 'Nurse anaesthetists', British Medical Journal (28 September 1940): 429.

Pearce, Evelyn, A General Textbook of Nursing: A Comprehensive Guide to the Final State Examinations (London: Faber and Faber, 1937).

Philip, Cornelius B., 'Tsutsugamushi disease (scrub typhus) in World War II', The Journal of Parasitology 34, 3 (June 1948): 169-91.

Romanis, W.H.C., 'Amputation in war time', Nursing Times (15 June 1940): 266-7.

Schofield, E.R., 'Benghazi', in Queen Alexandra's Royal Army Nursing Corps Association, The Gazette 3, 5 (1958): 5-7.

Skimming, Sylvia, Sand in My Shoes: The Tale of a Red Cross Welfare Officer with British Hospitals Overseas in the Second World War (Edinburgh: Oliver and Boyd, 1948).

Slater, Eliot, 'Psychological aspects of family life', in Sir James Marchant (ed.), Rebuilding Family Life in the Post-War World: An Enquiry with Recommendations (London: Odhams Press, 1945).

Stanford Read, Charles, 'The nurse and the psychological emergencies of war', Nursing Mirror (16 September 1939): 319-20.

Stanley-Sykes, W., 'Nurse anaesthetists', British Medical Journal (1 March 1941): 339.

Stokes, John F., 'The present status of the sulphonamide drugs', Nursing Times (21 February 1942): 124-5. 
Telshaw Camp, LaVonne, Lingering Fever: A World War II Nurse's Memoir (Jefferson, NC: McFarland, 1997).

Turner, S.C., 'All in the day's work. III - Nursing on a troopship', Nursing Times (17 January 1942): 76.

Wakeley, Cecil P.G.. 'The treatment of war burns', Nursing Times (11 October 1941): 819-24.

Weeks-Shaw, Clara, A Text-Book of Nursing: For the Use of Training Schools, Families and Private Students (3rd edn) (New York: D. Appleton and Company, 1906).

Wells, C.A., 'Post-war pattern: War-time advances in surgery', Nursing Times (9 June 1945): 368-69 and 373.

Wilks, Janet, Carbolic and Leeches (Ilfracombe: Arthur H. Stockwell, 1991).

Woods, H.B., 'Treatment of severe war-time burns', Nursing Times (5 November 1943): 821,827 and 833.

\section{Secondary sources}

Abrams, Lynn, Oral History Theory (London: Routledge, 2010).

Abrams, Lynn, 'Liberating the female self: Epiphanies, conflict and coherence in the life stories of post-war British women', Social History 39, 1 (2014): 14-35.

Acton, Carol, "'Stepping into history": Reading the Second World War through Irish women's diaries', Irish Studies Review 18, 1 (2010): 39-56.

Adams, Iain, 'A game for Christmas? The Argylls, Saxons and football on the Western Front, December 1914', The International Journal of the History of Sport 32, 11-12 (2015): 1395-415.

Aiston, Sarah, 'A maternal identity? The family lives of British women graduates pre- and post-1945', History of Education 34, 4 (2005): 407-26.

Alwis, Anne P., 'Men in pain: masculinity, medicine and the Miracles of St. Artemios', Byzantine and Modern Greek Studies 36, 1 (2012): 1-19.

Anderson, Julie, War, Disability and Rehabilitation in Britain: 'Soul of a Nation' (Manchester: Manchester University Press, 2011).

Archer, Bernice, and Fedorowich, Kent, 'The women of Stanley: Internment in Hong Kong, 1942-45', Women's History Review 5, 3 (1996): 373-99.

Astedt-Kurki, Paivi, and Isola, Arja, 'Humour between nurses and patient, and among staff: Analysis of nurses' diaries', Journal of Advanced Nursing 35, 3 (2001): 452-8.

Baly, Monica E., Nursing and Social Change (London: Routledge, 1995).

Bardgett, Suzanne, and Cesarani, David (eds), Belsen 1945, New Historical Perspectives (London: Vallentine Mitchell, 2006).

Bashford, Alison, Purity and Pollution: Gender, Embodiment and Victorian Medicine (Basingstoke: Macmillan, 1998).

Bassett, Jan, Guns and Brooches: Australian Army Nursing from the Boer War to the Gulf War (Oxford: Oxford University Press, 1992). 
Beaumont, Caitriona, 'Citizens not feminists: The boundary negotiated between citizenship and feminism by mainstream women's organisations in England, 1928-39', Women's History Review 9, 2 (2000): 411-29.

Beaumont, Caitriona, 'The women's movement, politics and citizenship, 19181950s', in Ina Zweiniger-Bargielowska (ed.), Women in Twentieth-Century Britain (Harlow: Pearson Education, 2001).

Beck, Cheryl Tatano, 'Humor in nursing practice: A phenomenological study', International Journal of Nursing Studies 34, 5 (1997): 346-52.

Benjamin, David, 'Afterword', The Home: Words, Interpretations, Meanings and Environments (Aldershot: Ashgate, 1995).

Berger Gluck, Sherna, and Patai, Daphne, 'Introduction', in Sherna Berger Gluck and Daphne Patai (eds), Women's Words: The Feminist Practice of Oral History (London: Routledge, 1991).

Bessel, Richard, and Schumann, Dirk (eds), Life after Death: Approaches to a Cultural and Social History of Europe during the 1940s and 1950s (Cambridge: Cambridge University Press, 2003).

Bessel, Richard, and Schumann, Dirk, 'Introduction: Violence, normality, and the construction of postwar Europe', in Richard Bessel and Dirk Schumann (eds), Life after Death: Approaches to a Cultural and Social History of Europe during the 1940s and 1950s (Cambridge: Cambridge University Press, 2003).

Biedermann, Narelle, 'The voices of days gone by: Advocating the use of oral history in nursing', Nursing Inquiry 8 (2001): 61-2.

Bingham, Adrian, "An era of domesticity": Histories of women and gender in interwar Britain', Cultural and Social History 1 (2004): 225-33.

Bingham, Adrian, 'Enfranchisement, feminism and the modern woman: Debates in the British popular press, 1918-1939', in Julie V. Gottlieb and Richard Toye (eds), The Aftermath of Suffrage: Women, Gender, and Politics in Britain 1918-1945 (Basingstoke: Palgrave Macmillan, 2013).

Bland, Lucy, 'White women and men of colour: Miscegenation fears in Britain after the Great War', Gender and History 17, 1 (2005): 29-61.

Bornat, Joanna, 'A second take: Revisiting interviews with a different purpose', Oral History 31, 1 (2003): 47-53.

Boschma, Geertje, Scaia, Margaret, Bonifacio, Nerrisa, and Roberts, Erica, 'Oral history research', in Sandra B. Lewenson and Eleanor Krohn Herrmann (eds), Capturing Nursing History: A Guide to Historical Methods in Research (New York: Springer, 2008).

Boschma, Geertje, Roberts, Erica, Dhari, Ranjit, Mahabir, Gilda, Walter, Susan, and Haney, Catherine, "Nobody ever asked me about my career": Public health nurses' oral histories preserved', The Bulletin of the UK Association for the History of Nursing 4 (2015): 43-51.

Bourke, Joanna, Dismembering the Male: Men's Bodies, Britain and the Great War (London: Reaktion Books, 1996).

Bourke, Joanna, 'Disciplining the emotions: Fear, psychiatry and the Second 
World War', in Roger Cooter, Mark Harrison and Steve Sturdy (eds), War, Medicine and Modernity (Stroud: Sutton Publishing, 1998).

Bourke, Joanna, The Second World War: A People's History (Oxford: Oxford University Press, 2001).

Bourke, Joanna, The Story of Pain: From Prayer to Painkillers (Oxford: Oxford University Press, 2014).

Braybon, Gail, and Summerfield, Penny, Out of the Cage: Women's Experiences in Two World Wars (London: Pandora, 1987).

Brock, Julia, Dickey, Jennifer W., Harker, Richard J.W., and Lewis, Catherine M. (eds), Beyond Rosie: A Documentary History of Women and World War II (Fayetteville, AK: University of Arkansas Press, 2015, Kindle edition).

Brooks, Jane, "Visiting rights only": The early experience of nurses in higher education, 1918-1960' [unpublished PhD thesis] (London: London School of Hygiene and Tropical Medicine, 2005).

Brooks, Jane, “"Uninterested in anything except food”: Nurse feeding work with the liberated inmates of Bergen-Belsen', Journal of Clinical Nursing 21 (2012): 2958-65.

Brooks, Jane, 'Nursing typhus victims in the Second World War, 1942-1944', Journal of Advanced Nursing 70, 7 (2014): 1510-19.

Brooks, Jane, “The nurse stoops down ... for me”: Nursing the liberated persons at Bergen-Belsen', in Jane Brooks and Christine E. Hallett (eds), One Hundred Years of Nursing Wartime Practices, 1854-1953 (Manchester: Manchester University Press, 2015).

Brooks, Jane, 'Wartime nursing: Feeding as forgotten practice', in Sandra B. Lewenson, Annemarie McAllister and Kylie Smith (eds), Nursing History for Contemporary Role Development (New York: Springer, 2017).

Brooks, Jane, and Hallett, Christine E., 'Introduction: The practice of nursing and the exigencies of war', in Jane Brooks and Christine E. Hallett (eds), One Hundred Years of Wartime Nursing Practices, 1854-1953 (Manchester: Manchester University Press, 2015).

Brooks, Jane, and Hallett, Christine E. (eds), One Hundred Years of Nursing Wartime Practices, 1854-1953 (Manchester: Manchester University Press, 2015).

Brooks, Jane, and Rafferty, Anne Marie, 'Dress and distinction in nursing, 1860-1945: “A corporate (as well as corporeal) armour of probity and purity", Women's History Review 16, 1 (2007): 41-57.

Brown, Kevin, Fighting Fit: Health, Medicine and War in the Twentieth Century (Stroud: The History Press, 2008, Kindle edition).

Brown, William R., 'The American girl and the Christmas tree: World War II soldier poets look at what the GIs were fighting for', Journal of American Culture 8, 2 (1985): 25-30.

Bruley, Sue, Women in Britain since 1900 (Basingstoke: Palgrave Macmillan, 1999). 
Brundage, Anthony, Going to the Sources: A Guide to Historical Research and Writing (Hoboken, NJ: Wiley Blackwell, 2017).

Bud, Robert, Penicillin: Triumph and Tragedy (Oxford: Oxford University Press, 2007).

Buhler-Wilkerson, Karen, No Place Like Home: A History of Nursing and Home Care in the United States (Baltimore, MD: Johns Hopkins University Press, 2001).

Burke Odland, Sarah, 'Unassailable Motherhood, Ambivalent Domesticity: The Construction of Maternal Identity in Ladies' Home Journal in 1946', Journal of Communication Inquiry 34, 1 (2010): 61-84.

Burris, Marsha L., Paradox of Professionalism: American Nurses in World War II (Charlotte: Spiral Publications, 2007).

Byrski, Liz, 'Emotional labour as war work: Women up close and personal with McIndoe's Guinea Pigs', Women's History Review 21, 3 (July 2012): 341-61.

Cade, Stanford, 'Burns in the Royal Air Force', Medical Training Establishment and Dept Royal Air Force Journal 1 (1941): 1-2.

Caine, Barbara, English Feminism, 1780-1980 (Oxford: Oxford University Press, 2001).

Callaway, Barbara J., Hildegard Peplau: Psychiatric Nurse of the Century (New York: Springer, 2002).

Canning, Deebs, Rosenberg, John P., and Yates, Patsy, 'Therapeutic relationships in specialist palliative care nursing practice', International Journal of Palliative Nursing 13, 5 (2007): 222-9.

Canning, Kathleen, 'The body as method? Reflections on the place of the body in gender history', Gender and History 11, 3 (1999): 499-513.

Carden-Coyne, Ana, The Politics of Wounds: Military Patients and Medical Power in the First World War (Oxford: Oxford University Press, 2014).

Carr, Gilly, and Mytum, Harold (eds), Cultural Heritage and Prisoners of War: Creativity Behind Barbed Wire (London: Routledge, 2012)

Carr, Gilly, Sanders, Paul, and Willmot, Louise (eds), Protest, Defiance and Resistance in the Channel Islands German Occupation, 1940-45 (London: Bloomsbury, 2014).

Celinscak, Mark, 'At war's end: Allied forces at Bergen-Belsen' [unpublished PhD thesis] (Toronto: York University, 2012).

Church, Olga M., and Johnson, M.L., 'Worth remembering: The process and products of oral history', International History of Nursing Journal 1, 1 (1995): $23-4$.

Connerton, Winifred, 'American nurses in colonial settings', in Patricia D'Antonio, Julie A. Fairman and Jean C. Whelan (eds), Routledge Handbook on the Global History of Nursing (London: Routledge, 2013)

Cooper, Joanne E., 'Shaping meaning: Women's diaries, journals and letters - the old and the new', Women's Studies International Forum 10, 1 (1987): 95-9.

Cooter, Roger, and Sturdy, Steve, 'Of war, medicine and modernity', in Roger 
Cooter, Mark Harrison and Steve Sturdy (eds), Medicine and Modern Warfare (Amsterdam: Rodopi, 1998).

Costello, John, Love, Sex and War: Changing Values 1939-45 (London: Collins, 1985).

Cowman, Krista, and Jackson, Louise A., 'Middle-class women and professional identity', Women's History Review 14, 2 (2005): 165-79.

Crang, Jeremy A., "'Come into the Army Maud": Women, military conscription, and the Markham Inquiry', Defence Studies 8, 3 (2008): 381-95.

Crew, F.A.E., The Army Medical Services: Volume I: Administration (London: HMSO, 1953).

Crew, F.A.E., The Army Medical Services: Volume II: Campaigns: Hong Kong, Malaya, Iceland and the Faroes, Libya, 1942-1943, North West Africa (London: HMSO, 1957).

Crew, F.A.E., 'The Army medical services', in Arthur Salusbury MacNalty and W. Franklin Mellor (eds), Medical Services in War: The Principal Medical Lessons of the Second World War (London: HMSO, 1968).

Dale, Charlotte, 'Traversing the veldt with "Tommy Atkins": The clinical challenges of nursing typhoid patients during the Second Anglo-Boer War (1899-1902)', in Jane Brooks and Christine E. Hallett (eds), One Hundred Years of Wartime Nursing Practices, 1854-1953 (Manchester: Manchester University Press, 2015).

Dale, Charlotte, 'The social exploits and behaviour of nurses during the AngloBoer War, 1899-1902', in Helen Sweet and Sue Hawkins (eds), Colonial Caring: A History of Colonial and Post-Colonial Nursing (Manchester: Manchester University Press, 2015).

Das, Santanu, Touch and Intimacy in First World War Literature (Cambridge: Cambridge University Press, 2005).

Davidoff, Leonore, Worlds Between: Historical Perspectives on Gender and Class (Cambridge: Polity Press, 1995).

Davin, Anna, 'Imperialism and motherhood', History Workshop Journal 5 (1978): 9-65.

DeGroot, Gerard J., "Lipstick on her nipples, cordite in her hair": Sex and romance among British servicewomen during the Second World War', in Gerard J. DeGroot and Corinna Peniston-Bird, A Soldier and a Woman (Abingdon: Taylor and Francis, 2014).

DiCenzo, Maria, "'Our Freedom and its Results": Measuring progress in the aftermath of suffrage', Women's History Review 23, 3 (2014): 421-40.

Dickinson, Tommy, 'Curing Queers': Mental Nurses and their Patients, 1935-74 (Manchester: Manchester University Press, 2015).

Dingwall, Robert, Rafferty, Anne Marie, and Webster, Charles, An Introduction to the Social History of Nursing (London: Routledge, 1988).

Dixon Vuic, Kara, “Officer, nurse, woman”: Army Nurse Corps recruitment for the Vietnam War', Nursing History Review 14 (2006): 111-59. 
Dixon Vuic, Kara, Officer, Nurse, Woman: The Army Nurse Corps in the Vietnam War (Baltimore, MD: Johns Hopkins University Press, 2010, Kindle edition).

Dixon Vuic, Kara, 'Wartime nursing and power', in Patricia D'Antonio, Julie A. Fairman and Jean C. Whelan (eds), Routledge Handbook on the Global History of Nursing (London: Routledge, 2013).

Doughty, Dorothy B., 'History of ostomy surgery', Journal of Wound Ostomy Continence Nursing 35,1 (2008): 34-8.

Dyhouse, Carol, 'Women students and the London Medical Schools, 1914-39: The anatomy of a masculine culture', Gender and History 10, 1 (1998): 110-32.

Dyhouse, Carol, 'Troubled identities: gender and status in the history of the mixed college in English universities since 1945', Women's History Review 12, 2 (2006) 169-94.

Easingwood, Ruth, "II was merely a shorthand typist”: British women at work in the British zone of occupied Germany, 1945-1949', Women's History Magazine 67 (2011): 20-7.

Enloe, Cynthia, Does Khaki Become You? The Militarization of Women's Lives (London: Pandora, 1988).

Evans, Richard J., The Third Reich at War (London: Penguin, 2009).

Fairman, Julie, 'Alterative visions: the nurse-technology relationship in the context of the history of technology', Nursing History Review 6 (1998): 129-46.

Fairman, Julie, and D'Antonio, Patricia, 'Virtual power: Gendering the nursetechnology relationship', Nursing Inquiry 6, 3 (1999): 178-86.

Fairman, Julie, and D'Antonio, Patricia, 'Reimagining nursing's place in the history of clinical practice', Journal of the History of Medicine and Allied Health Sciences 63, 4 (2008): 435-46.

Fairman, Julie, and Lynaugh, Joan E., Critical Care Nursing: A History (Philadelphia, PA: University of Pennsylvania Press, 1998).

Fennell, Jonathan, 'Courage and cowardice in the North African Campaign: The Eighth Army and defeat in the summer of 1942', War in History 20,1 (2013): 99-122.

Finlay, Adrianne, 'Cherry Ames, disembodied nurse: War sexuality, and sacrifice in the novels of Helen Wells', The Journal of Popular Culture 43, 6 (2010): 1189-206.

Flanagan, Ben, and Bloxham, Donald (eds), Remembering Belsen: Eyewitnesses Record the Liberation (London: Vallentine Mitchell, 2005).

Fletcher, Angharad, 'Sisters behind the wire: Reappraising Australian military nursing and internment in the Pacific during World War II', Medical History 55 (2011): 419-24.

Flynn, Karen, 'Proletarianization, professionalization and Caribbean immigrant nurses', Canadian Woman Studies 18, 1 (1998): 57-60.

Fussell, Paul, Wartime: Understanding and Behavior in the Second World War (New York: Oxford University Press, 1989). 
Gilbert, Martin, The Second World War: A Complete History (London: Phoenix, 2009).

Gilmour, Jean A., 'Hybrid space: Constituting the hospitals as a home space for patients', Nursing Inquiry 13, 1 (2006): 16-22.

Goodman, Phil, “Patriotic femininity”: Women's morals and men's morale during the Second World War', Gender and History 10, 2 (1998): 278-93.

Gottlieb, Julie V., 'Munich by-elections, 1938-1939', in Julie V. Gottlieb and Richard Toye, The Aftermath of Suffrage: Women, Gender, and Politics in Britain 1918-1945 (Basingstoke: Palgrave Macmillan, 2013).

Gottlieb, Julie V., and Toye, Richard, The Aftermath of Suffrage: Women, Gender, and Politics in Britain 1918-1945 (Basingstoke: Palgrave Macmillan, 2013).

Grayzel, Susan R., "Fighting for the idea of home life": Mrs Miniver and Anglo-American representations of domestic morale', in Philippa Levine and Susan R. Grayzel (eds), Gender, Labour, War and Empire (London: Palgrave Macmillan, 2009).

Grayzel, Susan R., At Home and Under Fire: Air Raids and Culture in Britain from the Great War to the Blitz (Cambridge: Cambridge University Press, 2012).

Greenberg, M., 'Therapeutic play: Developing humor in the nurse-patient relationship', Journal of the New York State Nurses Association 34, 1 (2003): 25-31.

Gregg, Alan, 'Adaptation of survival: Reflections on our postwar problems', American Journal of Nursing 44, 10 (1944): 923-7.

Gubar, Susan, "This is my rifle, this is my gun": World War II and the blitz on women', in Margaret Randolph Higonnet, Jane Jenson, Sonya Michel and Margaret Collins Weitz (eds), Behind the Lines: Gender and the Two World Wars (New Haven, CT: Yale University Press, 1987).

Hadley Jackson, Margaret, 'Causes and significance of the dwindling family', in Sir James Marchant (ed.), Rebuilding Family Life in the Post-War World: An Enquiry with Recommendations (London: Odhams Press, 1945).

Haggart, Ali, "'Desperate housewives" and the domestic environment in postwar Britain: Individual perspectives', Oral History 37, 1 (2009): 53-60.

Hall, Martha L., Orzada, Belinda T., and Lopez-Gydosh, Dilia, 'American women's wartime dress: Sociocultural ambiguities regarding women's roles during World War II', The Journal of American Culture 38, 3 (2015): 232-42.

Hallam, Julia, Nursing the Image: Media, Culture and Professional Identity (London: Routledge, 2000).

Hallett, Christine E., 'The personal writings of First World War nurses: A study of the interplay of authorial intention and scholarly interpretation', Nursing Inquiry 14, 4 (2007): 320-9.

Hallett, Christine E., Containing Trauma: Nursing Work in the First World War (Manchester: Manchester University Press, 2009).

Hallett, Christine E., Veiled Warriors: Allied Nurses of the First World War (Oxford: Oxford University Press, 2014).

Hallett, Christine E., “This fiendish mode of warfare”: Nursing the victims 
of gas poisoning in the First World War', in Jane Brooks and Christine E. Hallett (eds), One Hundred Years of Wartime Nursing Practices, 1854-1953 (Manchester: Manchester University Press, 2015).

Hallett, Christine E., Nurse Writers of the Great War (Manchester: Manchester University Press, 2016).

Hardman, Leslie, and Goodman, Cecily, The Survivors: The Story of the Belsen Remnant (London: Vallentine Mitchell, 2009).

Harris, Kirsty, More than Bombs and Bandages: Australian Army Nurses at Work in World War I (Newport: Big Sky Publishing, 2011, Kindle edition).

Harris, Kirsty, "Health, healing and harmony": Invalid cookery and feeding by Australian nurses in the Middle East in the First World War', in Jane Brooks and Christine E. Hallett (eds), One Hundred Years of Wartime Nursing Practices, 1854-1953 (Manchester: Manchester University Press, 2015).

Harrison, Mark, 'The medicalization of war - the militarization of medicine', The Society for the Social History of Medicine 9, 2 (1996): 267-76.

Harrison, Mark, Medicine and Victory: British Military Medicine in the Second World War (Oxford: Oxford University Press, 2004).

Harrison, Mark, The Medical War: British Military Medicine in the First World War (Oxford: Oxford University Press, 2010).

Hawkins, Sue, Nursing and Women's Labour in the Nineteenth Century: The Quest for Independence (London: Routledge, 2010).

Hay, Ian, One Hundred Years of Army Nursing: The Story of the British Army Nursing Services from the Time of Florence Nightingale to the Present Day (London: Cassell, 1953).

Helmstadter, Carol, 'Class, gender and professional expertise: British military nursing in the Crimean War', in Jane Brooks and Christine E. Hallett (eds), One Hundred Years of Wartime Nursing Practices, 1854-1953 (Manchester: Manchester University Press, 2015).

Henderson, Virginia, The Nature of Nursing: Reflections after 25 Years (New York: National League for Nursing Press, 1991).

Higonnet, Margaret Randolph, and Higonnet, Patrice L.-R., 'The double helix', in Margaret Randolph Higonnet, Jane Jenson, Sonya Michel and Margaret Collins Weitz (eds), Behind the Lines: Gender and the Two World Wars (New Haven, CT: Yale University Press,1987).

Higonnet, Margaret Randolph, Jenson, Jane, Michel, Sonya, and Weitz, Margaret Collins, 'Introduction', in Margaret Randolph Higonnet, Jane Jenson, Sonya Michel and Margaret Collins Weitz (eds), Behind the Lines: Gender and the Two World Wars (New Haven, CT: Yale University Press,1987).

Higonnet, Margaret Randolph, Jenson, Jane, Michel, Sonya, and Weitz, Margaret Collins (eds), Behind the Lines: Gender and the Two World Wars (New Haven, CT: Yale University Press, 1987).

Honey, Maureen, Creating Rosie the Riveter: Class, Gender, and Propaganda during World War II (Amherst, MA: University of Massachusetts Press, 1984). 
Howell, Jessica, Rafferty, Anne Marie, and Snaith, Anna, '(Author)ity abroad: The life writing of colonial nurses', International Journal of Nursing Studies 48 (2011): 1155-62.

Howell, Jessica, Rafferty, Anne Marie, Wall, Rosemary, and Snaith, Anna, 'Nursing the tropics: Nurses as agents of imperial hygiene', Journal of Public Health 35, 2 (2013): 338-41.

Jackson, Angela, 'Blood and guts: Nursing with the International Brigades in the Spanish Civil War, 1936-39', in Jane Brooks and Christine E. Hallett (eds), One Hundred Years of Nursing Wartime Practices, 1854-1953 (Manchester: Manchester University Press, 2015).

Jalland, Pat, 'A culture of silent grief? The transformation of bereavement care in 20th century England', Bereavement Care 32, 1 (2013): 16-22.

Jones, Edgar, and Wessely, Simon, 'Psychiatric battle casualties: An intra- and interwar comparison', The British Journal of Psychiatry 178 (2001): 242-7.

Justham, David, “"Those maggots - they did a wonderful job”: The nurses' role in wound management in civilian hospitals during the Second World War', in Jane Brooks and Christine E. Hallett (eds), One Hundred Years of Nursing Wartime Practices, 1854-1953 (Manchester: Manchester University Press, 2015).

Kenyon, Olga, 800 Years of Women's Letters (Stroud: Alan Sutton Publishing, 1992).

Khan, Yasmin, 'Sex in an imperial war zone: Transnational encounters in Second World War India', History Workshop Journal 73 (2012): 241-58.

Kushner, Tony, 'The memory of Belsen', in Jo Reilly, David Cesarani, Tony Kushner and Colin Richmond (eds), Belsen in History and Memory (London: Frank Cass, 1997).

Laffin, John, Women in Battle (London: Abelard Schuman, 1967).

Lamb, M.M., 'Nursing is what?', International Nursing Review 17 (1970): 373-80.

Lawler, Jocalyn, Behind the Screens: Nursing, Somology and the Problem of the Body (Melbourne: Churchill Livingstone, 1991).

Lewenson, Sandra B., 'Doing historical research', Sandra B. Lewenson and Eleanor Krohn Herrmann (eds), Capturing Nursing History: A Guide to Historical Methods in Research (New York: Springer, 2008).

Lewenson, Sandra B., and Krohn Herrmann, Eleanor (eds), Capturing Nursing History: A Guide to Historical Methods in Research (New York: Springer, 2008).

Linker, Beth, War's Waste: Rehabilitation in World War I America (Chicago: University of Chicago Press, 2011).

Lockertsen, Jan Thore, Fause, Ashild, Hallett, Christine E., and Brooks, Jane, 'The Norwegian Mobile Army Surgical Hospital: Nursing at the front', in Jane Brooks and Christine E. Hallett (eds), One Hundred Years of Nursing Wartime Practices, 1854-1953 (Manchester: Manchester University Press, 2015).

Lucas, James, War in the Desert: The Eighth Army at El Alamein (London: Arms and Armour Press, 1982). 
McBryde, Brenda, Quiet Heroines: Nurses of the Second World War (London: Chatto and Windus, 1985).

McEwan, Ian, Atonement (London: Vintage Books, 2002).

McGann, Susan, The Battle of the Nurses (Middlesex: Scutari Press, 1992).

MacGuire, Jillian, 'Tailoring research for therapeutic nursing practice', in Richard McMahon and Alan Pearson, Nursing as Therapy (2nd edn) (Cheltenham: Stanley Thornes, 1998).

McIntosh, Jean, and Dingwall, Robert, 'Teamwork in theory and practice', in Robert Dingwall and Jean McIntosh (eds), Readings in the Sociology of Nursing (Edinburgh: Churchill Livingstone, 1978).

MacNalty, Arthur Salusbury, 'Medical research', in Arthur Salusbury MacNalty and W. Franklin Mellor (eds), Medical Services in War: The Principal Medical Lessons of the Second World War (London: HMSO, 1968).

MacNalty, Arthur Salusbury, and Mellor, W. Franklin (eds), Medical Services in War: The Principal Medical Lessons of the Second World War (London: HMSO, 1968).

Mackie, Mary, Sky Wards: A History of the Princess Mary's Royal Air Force Nursing Service (London: Robert Hale, 2001).

McMahon, Richard, 'Therapeutic nursing: Theory, issues and practice', in Richard McMahon and Alan Pearson, Nursing as Therapy (2nd edn) (Cheltenham: Stanley Thornes, 1998).

McPherson, Kathryn, Bedside Matters: The Transformation of Canadian Nursing, 1900-1990 (Toronto: Oxford University Press Canada, 1996).

Marwick, Arthur, The New Nature of History: Knowledge, Evidence, Language (Basingstoke: Palgrave, 2001).

Mayhew, Emily, The Reconstruction of Warriors: Archibald McIndoe, The Royal Air Force and the Guinea Pig Club (Barnsley: Greenhill Books, 2010, Kindle edition).

Meehan, Therese Connell, 'Careful nursing: A model for contemporary nursing practice', Journal of Advanced Nursing, 44, 1 (2003): 99-107.

Meyer, Leisa D., Creating GI Jane: Sexuality and Power in the Women's Army Corps During World War II (New York: Columbia University Press, 1996).

Minister of Health, Secretary of State for Scotland and the Minister of Labour and National Service, 'Staffing the hospitals: An urgent national need', International History of Nursing Journal 3, 3 (1998): 15. Reprinted from pamphlet, Minister of Health, Secretary of State for Scotland and the Minister of Labour and National Service, 'Staffing the hospitals: An urgent national need' (London: HMSO, 1945) RCN Archives, Pamphlet Collection 11AD, RCN Archives, Edinburgh.

Moeller, Robert G., 'What did you do in the war, mutti? Courageous women, compassionate commanders and stories of the Second World War', German History 22, 4 (2004): 563-94.

Montgomerie, Deborah, 'Assessing Rosie: World War II, New Zealand 
women and the iconography of femininity', Gender and History, 8, 1 (1996): $108-32$.

Moore, Jeanne, 'Placing the home in context', Journal of Environmental Psychology 20 (2000): 207-17.

Mortimer, Barbara, Sisters: Extraordinary True-Life Stories from Nurses in World War Two (London: Hutchinson, 2012).

Nestel, Sheryl, '(Ad)ministering angels: Colonial nursing and the extension of empire in Africa', Journal of Medical Humanities 19, 4 (1998): 257-77.

Neushul, Peter, 'Fighting research: Army participation in the clinical testing and mass production of penicillin during the Second World War', in Roger Cooter, Mark Harrison and Steve Sturdy (eds), War, Medicine and Modernity (Stroud: Sutton Publishing, 1998).

Newlands, Emma, Civilians into Soldiers: War, the Body and British Army Recruits, 1939-45 (Manchester: Manchester University Press, 2014).

Noakes, Lucy, War and the British: Gender, Memory and National Identity (London: I.B. Tauris, 1998).

Noakes, Lucy, Women in the British Army: War and the Gentle Sex, 1907-1948 (London, Routledge, 2006, Kindle edition).

Noakes, Lucy, "Serve to save": Gender, citizenship and Civil Defence in Britain, 1937-41', Journal of Contemporary History 47, 4 (2012): 734-53.

Noakes, Lucy, "Gentle in manner, resolute in deed": Women and the British army in the post-war years', Women's History Magazine 76 (Autumn 2014): 5-12.

Norman, Elizabeth M., and Eifried, Sharon, 'How did they all survive? An analysis of American nurses' experiences in Japanese Prisoner-of-War camps', Nursing History Review 3 (1995): 105-27.

Ondaatje, Michael, The English Patient (London: Bloomsbury, 1992).

Parry, Joyce Ffoulkes, Joyce's War: The Second World War Journal of a Queen Alexandra's Imperial Military Nursing Service Nurse, ed. Rhiannon Evans (Stroud: The History Press, 2015, Kindle edition).

Pattinson, Juliette, "Playing the daft lassie with them": Gender, captivity and the Special Operations Executive during the Second World War', European Review of History 13, 2 (2006): 271-92.

Pattinson, Juliette, Behind Enemy Lines: Gender, Passing and the Special Operations Executive in the Second World War (Manchester: Manchester University Press, 2007).

Peniston-Bird, Corinna, 'Classifying the body in the Second World War: British men in and out of uniform', Body and Society 9, 4 (2003): 31-48.

Perks, Robert, and Thomson, Alastair, The Oral History Reader (London: Routledge, 1998).

Piggott, Juliet, Queen Alexandra's Royal Army Nursing Corps (London: Leo Cooper, 1975).

Poovey, Mary, Uneven Developments: The Ideological Work of Gender in MidVictorian England (Chicago: University of Chicago Press, 1988). 
Porter, Dorothy, Health, Civilization and the State: A History of Public Health from Ancient to Modern Times (London: Routledge, 1999).

Purvis, June, 'Using primary sources when researching women's history from a feminist perspective', Women's History Review 1, 2 (1992): 273-306.

Rae, Ruth, Scarlet Poppies: The Army Experience of Australian Nurses during World War I (Burwood: College of Nursing, 2004).

Rafferty, Anne Marie, The Politics of Nursing Knowledge (London: Routledge, 1996).

Reilly, Jo, Cesarani, David, Kushner, Tony, and Richmond, Colin (eds), Belsen in History and Memory (London: Frank Cass, 1997).

Reilly, Jo, 'Cleaner, carer and occasional dance partner? Writing women back into the liberation of Bergen-Belsen', in Jo Reilly, David Cesarani, Tony Kushner and Colin Richmond (eds), Belsen in History and Memory (London: Frank Cass, 1997).

Richardson, Sharon L., "Stand up and be counted": Nursing at the Calgary General Hospital after the Second World War', Canadian Bulletin of Medical History 18 (2001): 297-323.

Rickard, Wendy, 'Oral history - "More dangerous than therapy"? Interviewees' reflections on recording traumatic or taboo issues', Oral History 26, 2, 'Memory, Trauma and Ethics' (1998): 34-48.

Rogers, Anna, While You're Away: New Zealand Nurses at War, 1899-1948 (Auckland: Auckland University Press 2003).

Roper, Michael, 'Between Manliness and Masculinity: The "War" Generation" and the Psychology of Fear in Britain, 1914-1950', Journal of British Studies 44 (2005): 343-62.

Rose, Sonya O., Which People's War? National Identity and Citizenship in Britain, 1939-1945 (Oxford: Oxford University Press, 2003, Kindle edition).

Rowbotham, Sheila, A Century of Women: A History of Women in Britain and the United States (London: Penguin, 1999).

Sandelowski, Margarete, 'Venous envy: The post-World War II debate over IV nursing', Advances in Nursing Science 22, 1 (1999): 52-62.

Sandelowski, Margarete, Devices and Desires: Gender, Technology and American Nursing (Chapel Hill, NC: University of North Carolina Press, 2000).

Sangster, Joan, "Telling our stories": Feminist debates and the use of oral history', Women's History Review 3, 1 (1994): 5-28.

Sarkar, Mahua, 'Between craft and method: Meaning and inter-subjectivity in oral history analysis', Journal of Historical Sociology 25, 4 (2012): 578-600.

Sarnecky, Mary, A History of the US Army Nurse Corps (Philadelphia, PA: University of Pennsylvania Press, 1999).

Schultz, Jane E., Women at the Front: Hospital Workers in Civil War America (Chapel Hill, NC: University of North Carolina Press, 2004).

Shephard, Ben, After Daybreak: The Liberation of Belsen, 1945 (London: Pimlico, 2005). 
Shephard, Ben, 'The medical relief at Belsen', in Suzanne Bardgett and David Cesarani (eds), Belsen 1945, New Historical Perspectives (London: Vallentine Mitchell, 2006).

Shkimba, M., and Flynn, Karen, “In England we did nursing”: Caribbean and British nurses in Great Britain and Canada, 1950-70', in Barbara Mortimer and Susan McGann (eds), New Directions in Nursing History: International Perspectives (London: Routledge, 2004).

Sintos Coloma, Roland, “White gazes, brown breasts”: Imperial feminism and disciplining desires and bodies in colonial encounters', Paedagogica Historica: International Journal of the History of Education 48, 2 (2012): 243-61.

Sixsmith, Judith, 'The meaning of home: An exploratory study of environmental experience', Journal of Environmental Psychology 6 (1986): 281-98.

Smith, Harold, 'The effect of the war on the status of women', in Harold Smith (ed.), War and Social Change: British Society in the Second World War (Manchester: Manchester University Press, 1986).

Smyth, John, The Will to Live: The Story of Dame Margot Turner (London: Hills and Lacy, 1970)

Solano, Diana, and Rafferty, Anne Marie, 'Can lessons be learned from history? The origins of the British imperial nurse labour market: A discussion paper', International Journal of Nursing Studies 44, 6 (2007): 1055-63.

Starns, Penny, 'Fighting militarism? British nursing during the Second World War', in Roger Cooter, Mark Harrison and Steve Sturdy (eds), War, Medicine and Modernity (Stroud: Sutton Publishing, 1998).

Starns, Penny, Nurses at War: Women on the Frontline, 1939-45 (Stroud: Sutton Publishing, 2000).

Starns, Penny, Surviving Tenko: The Story of Margot Turner (Stroud: The History Press, 2010).

Summerfield, Penny, 'What women learned from the Second World War', History of Education 18, 3 (1989): 213-29.

Summerfield, Penny, 'Women and war in the twentieth century', in June Purvis (ed.), Women's History: Britain, 1850-1945 (London: UCL Press, 1995).

Summerfield, Penny, 'Gender and war in the twentieth century', The International History Review 19, 1 (1997): 3-15.

Summerfield, Penny, Reconstructing Women's Wartime Lives: Discourse and Subjectivity in Oral Histories of the Second World War (Manchester: Manchester University Press, 1998).

Summerfield, Penny, “They didn't want women back in that job”: The Second World War and the construction of gendered work histories', Labour History Review 63, 1 (1998): 83-104.

Summerfield, Penny, 'Culture and composure: Creating narratives of the gendered self in oral history interviews', Cultural and Social History 1 (2004): 65-93.

Summerfield, Penny, and Peniston-Bird, Corinna, 'Women in the firing-line: The 
Home Guard and the defence of gender boundaries in Britain in the Second World War', Women's History Review 9, 2 (2000): 231-55.

Summers, Anne, Angels and Citizens: British Women as Military Nurses, 18541914 (Newbury: Threshold Press, 2000).

Sumners, Ann D., 'Professional nurses attitudes towards humour', Journal of Advanced Nursing 15 (1999): 194-200.

Sweet, Helen M., and Dougall, Rona, Community Nursing and Primary Healthcare in Twentieth-Century Britain (New York: Routledge, 2008).

Tanay, Mary Anne Lagmay, Roberts, Julia and Ream, Emma, 'Humour in adult cancer care: A concept analysis', Journal of Advanced Nursing 69, 9 (2012): 2131-40.

Taylor, Beverley, 'Ordinariness in nursing as therapy', in Richard McMahon and Alan Pearson, Nursing as Therapy (2nd edn) (Cheltenham: Stanley Thornes, 1998).

Taylor, Eric, Women Who Went to War, 1938-46 (London: Robert Hale, 1988).

Taylor, Eric, Front-Line Nurse: British Nurses in World War II (London: Robert Hale, 1997).

Taylor, Eric, Combat Nurse (London: Robert Hale, 1999).

Taylor, Eric, Wartime Nurse: 100 years from the Crimea to Korea 1854-1954 (London: Robert Hale, 2001).

Tesseyman, Sheri, 'Complex alliance: A study of relationships between nursing and medicine in Britain and the United States of America, 1860-1914' [unpublished PhD] (Manchester: University of Manchester, 2013).

Terraine, John, 'Christmas 1914, and after', History Today 29 (1979): 781-9.

Thane, Pat, 'What difference did the vote make? Women in public and private life in Britain since 1918', Historical Research 76, 192 (2003): 268-85.

Thane, Pat, 'Family life and "normality" in postwar British culture', in Richard Bessel and Dirk Schumann (eds), Life after Death: Approaches to a Cultural and Social History of Europe during the 1940s and 1950s (Cambridge: Cambridge University Press, 2003).

Thane, Pat, 'Girton Graduates: earning and learning, 1920s-1980s', Women's History Review 13, 3 (2004): 347-61.

Thompson, Paul, The Voice of the Past: Oral History (Oxford: Oxford University Press, 2000).

Thurgood, Graham J., 'Nurses' voices from the archives', Journal of the Society of Archivists 31, 2 (2010): 135-47.

Toman, Cynthia, 'Blood work: Canadian nursing and blood transfusion, 19421990', Nursing History Review 9 (2001): 51-78.

Toman, Cynthia, "Body work": Nurses and the delegation of medical technology at the Ottawa Civic Hospital, 1947-1972', Canadian Journal of the History of Science, Technology and Medicine 29, 2 (2006): 155-75.

Toman, Cynthia, An Officer and a Lady: Canadian Military Nursing and the Second World War (Vancouver: University of British Columbia Press, 2007). 
Toman, Cynthia, 'Front lines and frontiers: War as legitimate work for nurses, 1939-1945', Social History 40, 79 (2007): 45-74.

Toman, Cynthia, Sister Soldiers of the Great War: The Nurses of the Canadian Army Medical Corps (Vancouver: University of British Columbia Press, 2016).

Tosh, John, The Pursuit of History (London: Longman, 2002).

Travelbee, Joyce, Interpersonal Aspects of Nursing (Philadelphia, PA: F.A. Davis, 1971).

Traynor, Michael, Boland, Maggie, and Buus, Niels, 'Autonomy, evidence and intuition: Nurses and decision-making', Journal of Advanced Nursing 66, 7 (2010): 1584-91.

Twells, Alison, "Went into raptures": Reading emotion in the ordinary wartime diary, 1941-1946', Women's History Review 25, 1 (2016): 143-60.

Twomey, Christina, 'Australian nurse POWs: Gender, war and captivity', Australian Historical Studies 36, 124 (2004): 255-74.

Twomey, Christina, 'Double displacement: Western nurses return home from Japanese internment camps in Second World War', Gender and History 21, 3 (2009): 670-84.

Tyrer, Nicola, Sisters in Arms: British Army Nurses Tell their Story (London: Phoenix, 2008).

Valley, Myra, "The training of "Agents of Empire": Educational and early career patterns for Scottish nurses of the Colonial and Overseas Nursing Associations, 1899-1939', The Bulletin of the UK Association for the History of Nursing, 3 (2014): 57-72.

Vicinus, Martha, Independent Women: Work and Community for Single Women, 1850-1920 (London: Virago, 1985).

Vickery, Amanda, 'Historiographical review: Golden age to separate spheres? A review of the categories and chronology of English women's history', The Historical Journal 36, 2 (1993): 383-414.

Walby, Sylvia, and Greenwell, June, Medicine and Nursing: Professions in a Changing Health Service (London: Sage, 1994).

Warner, Lavinia, and Sandilands, John, Women Beyond the Wire: A Story of Prisoners of the Japanese, 1942-45 (London: Michael Joseph, 1982).

Watson, Janet S.K., 'Khaki girls, VADs, and Tommy's sister: Gender and class in First World War Britain', The International History Review 19, 1 (1997): 32-50.

Watson, Janet S.K., 'Wars in the wards: The social construction of medical work in First World War Britain', Journal of British Studies 41, 4 (2002): 484-510.

Watson, Janet S.K., Fighting Different Wars: Experience, Memory, and the First World War in Britain (Cambridge, Cambridge University Press, 2007).

Webster, Charles, 'Nursing as the early crisis of the NHS', International History of Nursing Journal 3, 3 (1998): 36-43.

Webster, Charles, The National Health Service: A Political History (Oxford: Oxford University Press, 2002).

Whitehead, Ian, 'The British medical officer on the Western Front', in Roger 
Cooter, Mark Harrison, and Steve Sturdy (eds), Medicine and Modern Warfare (Amsterdam: Rodopi, 1999).

Willmot, Louise, 'Women and resistance', in Gilly Carr, Paul Sanders and Louise Willmot (eds), Protest, Defiance and Resistance in the Channel Islands German Occupation, 1940-45 (London: Bloomsbury, 2014).

Yap, Felicia, 'Voices and silence of memory: Civilian internees of the Japanese in British Asia during the Second World War', Journal of British Studies 50 (October 2011): 917-40.

Yap, Felicia, 'Creativity and the body: Civilian internees in British Asia in the Second World War', in Gilly Carr and Harold Mytum (eds), Cultural Heritage and Prisoners of War: Creativity Behind Barbed Wire (London: Routledge, 2012).

Zweiniger-Bargielowska, Ina, 'Housewifery', in Ina Zweiniger-Bargielowska (ed.), Women in the Twentieth-Century (Harlow: Pearson Education, 2001). 